\title{
Effect of viewership and information on materialism and compulsive buying behavior- A comparative study of television and digital advertising
}

\author{
Farah Ahmad \\ College of Business Administration, Dar Al Uloom University, \\ Riyadh, Kingdom of Saudi Arabia. \\ Yasser Mahfooz \\ College of Business Administration, King Saud University, \\ Riyadh, Kingdom of Saudi Arabia.
}

\begin{abstract}
This comparative study between television and digital advertising explores the effect of viewership and information on compulsive buying behavior. To test the relationships in proposed framework, data was collected through self-administered questionnaires using convenience sampling technique. Out of 285 responses, 267 were chosen for the purpose of study and analyzed for descriptive statistics as well as relationship between information, materialism and buying behavior. Significant positive relationship was found between all dimensions. For both online and television advertising, viewership factors were found to have a higher impact than information on materialism. On compulsive buying behavior, viewership was more effective as compared to information, whereas for television advertising information had a greater effect.
\end{abstract}

Keywords: Television Advertisements, Digital Advertisements, Viewership, Information, Materialism, Compulsive Buying Behavior

\section{INTRODUCTION}

The communication process of advertisements and the response of viewers to various forms of advertising have been studied multiple times (Ghani \& Zain, 2004; Jayasinghe \& Ritson, 2013; Jin \& Lutz, 2013). Much research has been done on the effects and results related to the variables like broadcast, and social context on audience reception and engagement presented (Murry \& Dacin, 1996; Raghunathan \& Corfman, 2006). Recall of advertisements and attitude towards brand are studied (Murry et al., 1992). Advertising information and socially engaging advertisements have held the power over various viewers during the viewer event (Jayasinghe \& Ritson, 2013), and a theoretical framework about the advertising engagement and consumption in domestic settings by studying the culturally framed viewing contexts and practices was proposed. There are different studies within consumer research that are done in the advertising context which are largely derived from cognitive and social psychology. Researchers often adapt experimental methods to determine measures of advertising engagement and effectiveness (Jayasinghe \& Ritson, 2013).

Advertisements are an integral part of our society, and are a key source of communication for both consumers and businesses (Belch \& Belch, 2012). But the various forms of advertising like digital and television promote the imitation of western lifestyle (Assad, 2008). Businesses might be promoting their offering through advertising, whereas consumers might be discussing the offering on various channels like social media, internet forums, etc. The continuous exposure of consumers to advertisements from varied media has an effect on the lifestyle, attitude and buying behavior (Sutherland, 1993), which makes advertisers very keen 
to spend more on marketing promotion activities (Harper, 1975). The main goal of advertising is to help in the selling of the product and any form of advertising is not considered good unless it results in sales (Ha et al., 2011). It plays an important role in present market scenario as well as in influencing the consumers' buying decision.

Advertising is considered to be one of the most effective tools for marketing communication (Belch \& Belch, 2012; Clow \& Baack, 2014; Rajagopal, 2006). Researchers (Brassington \& Pettitt, 2003; Erdogan \& Baker, 1999; Redenbach, 2000) analyzed behavior of consumers and found them to be sensitive to communication. Advertising is an important tool of integrated marketing communication which is used to motivate the consumers emotionally for buying the product (Priya et al., 2010). The advertisements feature different products like fast food stuff, toys, chocolates, snacks, confectionaries and cookies. All of these are specifically targeted at children and all of them motivate the consumer to try new brands and keep buying (Arnas, 2006; Halford et al., 2004; Mittal et al., 2010; Sherry et al., 1999). The attitude of the consumer towards the advertisements develops from various factors, cognitive or affective in nature. While watching the advertisements and the factors associated with it, the needs, personality and ability to process information comes into play (Resnik et al., 1979).Advertising seems to be effective if it is liked by consumers. Advertisements of such types gain consumer attention and further create awareness among the consumer of the product that it might use and facilitates the involvement of the consumer. This further affects their behavior significantly. Biel and Bridgwater (1990) found that the likeability of advertisements have a persuasive effect toward a brand.

Researchers in marketing have studied most areas of consumer behavior including the impact of everything related to the purchase behavior of consumer, and how the products are consumed (Hawkins et al., 2010; Schiffman et al., 2010; Solomon, 2011). Frideres (1973) identified two effects of advertising campaigns. Firstly, it is a source of information for the audience, and secondly it creates a need for a product or service. This is the reason why marketing communication exercise from an advertiser is also found to create a trigger which ultimately leads to a buying decision.

One significant issue in marketing is an understanding of the effect of specific mass media like television or newspaper advertising on consumers (Razzouk \& Al-Khatib, 1993; Ghani, 2004; Woo et al., 2015). Business critics are concerned with the power of mass media to synthesize and stimulate wants. Defenders of mass media respond to this challenge by citing things such as the high failure rates of new products and the difficulties involved in changing consumers' attitudes (Belch \& Belch, 2012; Clow \& Baack, 2014; Moore \& Moschis, 1978).

The communication process of advertisements and the response of viewers to various forms of advertising have been studied multiple times (Razzouk, \& Al-Khatib, 1993; Ghani \& Zain, 2004; Jayasinghe \& Ritson, 2013; Jin \& Lutz, 2013). Much research has been done on the effects and results related to the variables like broadcast, and social context on audience reception and engagement presented (Murry \& Dacin, 1996; Raghunathan \& Corfman, 2006). Recall of advertisements and attitude towards brand are studied (Murry et al., 1992). Advertising information and socially engaging advertisements have held the power over various viewers during the viewer event (Jayasinghe \& Ritson, 2013), and a theoretical framework about the advertising engagement and consumption in domestic settings by studying the culturally framed viewing contexts and practices was proposed. 
This study focuses on effect of television and digital advertisements on the compulsive buying behavior of respondents in the Kingdom of Saudi Arabia. Not much literature exists on this topic for the country and the present study fulfils this gap. The present study tries to analyze whether television advertisements still can influence consumers or they are no more needed due to the existing digital advertising tools. This study is an extension of a previous study done by authors (Ahmad \& Mahfooz, 2018) which focused only on television advertising and its effect on buying behavior.

The research objectives are:

1. To study the influence of materialism on compulsive buying behavior.

2. To compare between television and digital advertisements for their effect on compulsive buying behavior.

\section{METHODOLOGY}

Research is available on the effects of television advertising, but not many recent research were found in the Saudi Arabian context with a focus on dimensions of advertising and influence on consumers. The present research addresses this issue and reinvestigates the direct and indirect relationships that are visible in the conceptualized model. The model has 5 dimensions (advertisement viewership, advertisement information, materialism, and compulsive buying behavior).

Various studies have addressed the effects of advertising (Ahmad \& Mahfooz, 2018; Karadeniz, 2013; North \& Kotze, 2001; Saraf, 2012; Yavas \& Abdul-Gader, 1993). Yet, these studies don't establish a relationship between perception towards online advertisements, and the compulsive buying behavior of consumers in Saudi Arabia.

The conceptual model is shown as figure 1.

H3

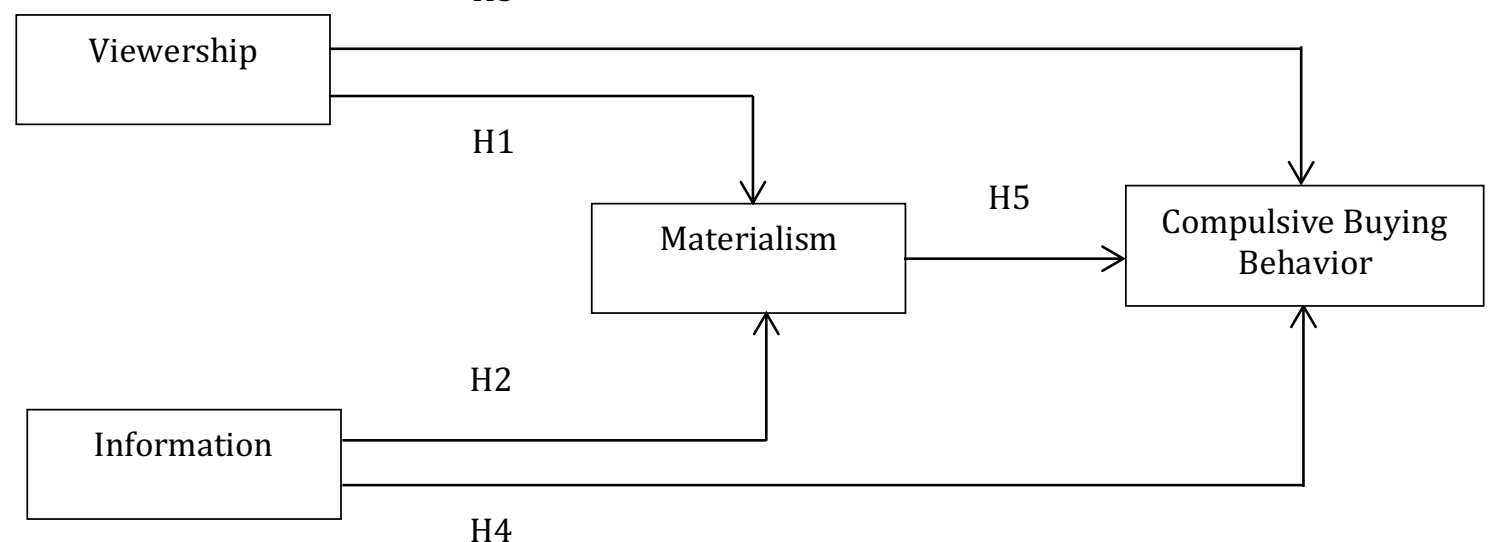

Figure 1: Conceptual Model

Advertisers opine that the main sources of consumer behavior and cognitions are parents and peers, and that advertising may actually create positive consumer socialization, such as socially desirable consumer behavior and greater knowledge of the consumption process (Ghani \& Zain, 2004; Ward \& Wackman, 1971). Mass media is effective for inducing long term changes in attitude and behavior towards products (Jarlbro, 2001; Jin \& Lutz, 2013), and the advertising exposure of consumers is affected by the intensity of advertisements during the process of viewing an advertisement (Abe, 1997). Researchers have found that advertising increases materialism in consumers (Buijzen \& Valkenburg, 2003; Greenberg \& Brand, 1993; Valkenburg \& Buijzen, 2005; Wulfemeyer \& Mueller, 1992). A positive influence has been found on 
materialism and an increase in a desire for the products from a (Chan, 2003; Yang \& Ganahl, 2004).

A report by Consumers International (1999) lists contemporary medium for advertising like product placement, merchandise, or fan clubs as a source of interpersonal communication stimulation. But there can be other sources of interpersonal influence, like parents or peers (Goldstein, 1999), which are often very strong in nature. The television advertisements cannot be isolated easily from these influences (Furnham, 2000) and an account of demography factors such as the age, household income, education of the consumer/viewer/ buyer, and the cultural background need to be taken into consideration while discussing it.

Materialism is defined as an orientation emphasizing possessions and money for personal happiness and social progress (Ward \& Wackman, 1971). Advertising provides information and exposes viewers to new products available in the market. Wulfemeyer and Mueller (1992) opine that the ideology of advertising is to inculcate thinking that goods and services are important to obtain success and create happiness. This also shows the materialistic influence of advertising. Goldberg and Gorn (1978), Greenberg and Brand (1993), and Moschis and Moore (1982) studied the materialistic influence of advertising.

Researchers have studied materialism and its effect (Hoffman et al., 2014; Islam, et al., 2017; Shek et al., 2014; Shoham et al., 2014; Segev et al., 2015; Shek et al., 2016; Tuu et al., 2017; Pradhan et al., 2018). Consumerism in Saudi Arabia can be attributed to the products imported from western countries (Ahmad \& Mahfooz, 2018). The macro environmental factors have led to the Saudi Arabian society becoming materialistic in nature (Assad, 2008). This leads to the following hypothesis:

H1: There is a positive effect of advertisement viewership on consumer materialism

H2: There is a positive effect of advertisement information on consumer materialism

Researchers have always worked to know the relationship between advertising and compulsive buying (Ashley et al. 1980; Kwak, Zinkhan, \& Dominick, 2002; Razzouk, \& AlKhatib, 1993; Roberts, Manolis, \& Tanner, 2003). Edwards and Potter (1992) defined compulsive buying as "a chronic abnormal form of shopping and spending characterized by the extreme, uncontrollable, and repetitive urge to buy, disregarding the consequences." Research has described compulsive buying behavior as a mental state in which an isolated individual who lacks impulse control and has low self-esteem combined with anxiety and materialism seeks excitement (Desarbo \& Edwards, 1996; Faber \& O'guinn, 1992; O'Guinn \& Faber, 1989; Valence, d'Astous, \& Fortier, 1988). According to Dittmar and Drury (2000), compulsive buyers believe that expensive material is essential for happiness and success much more than normal buyers believe this. Researchers have found that a higher materialistic value in an individual makes him desire for a higher status. A higher want of expensive possessions has also been found (Halliwell et al., 2005). Materialism is also found to be an influencer of compulsive buying behavior in individuals (Mowen \& Spears, 1999; Couchman, \& Sheldon, 2004; Yurchisin \& Johnson, 2004). Compulsive buying behavior is found to be a consequence of materialism (Halliwell, Dittmar, \& Howe, 2005). This leads to the following hypothesis:

H3: There is a positive effect of advertisement viewership on compulsive buying behavior

H4: There is a positive effect of advertisement information on compulsive buying behavior

H5: There is a positive effect of consumer materialism on compulsive buying behavior

The hypotheses need to be tested for relationship between variables (Neuman, 2007) which is done through a measurement scale which can be adapted or adopted from previous studies, or 
developed by the researcher (Churchill, 1979). The research variables for this study were also adapted from previous research. These are viewership, information, materialism, and compulsive buying behavior. The items for information and viewership were adapted from Chan and Cai (2009), and Jin and Lutz (2013); items for materialism were adapted from Moschis and Moore (1982), and Richins and Dawson (1992). The items for compulsive buying behavior were adapted from Valence et al. (1988), and Islam et al. (2017).

The initial questionnaire which had 24 items was reviewed by 2 academicians with significant research in advertising and brand management; and 2 advertising professionals. This ensures that the selection of scale items extends past just empirical issues to also include theoretical and practical considerations (Hair et al., 2010). It also evaluates the accuracy of tool used for measurement (questionnaire), and suggests if the items of scale cover the specific construct to be measured (Malhotra \& Dash, 2010). After screening by reviewers, 5 items were retained for viewership, all 5 for information, all 6 for materialism, and 5 for compulsive buying behavior.

The demographic data in questionnaire had multiple choice questions for gender, age, and education. The respondents were asked to provide a response to 21 items chosen after the process of content validity. A 5-point Likert scale was used with 1 =strongly disagree, $2=$ disagree, $3=$ neither agree nor disagree, $4=$ agree, and $5=$ strongly agree. The sampling units are all households with a personal television set(s) for regular viewing in Riyadh, Kingdom of Saudi Arabia, and access to internet (either home or mobile). Since Riyadh is the biggest city in the country and also has the largest population among all cities therefore it was chosen as a sample frame. A total of 267 responses were used for final analysis out of the 285 received (93.68\% valid response rate). The rejection of questionnaires was due to missing data as each respondent had to provide responses for both online and television advertising.

The questionnaires were administered to the respondents personally. This way the response rate is high, responses are fast, clarifications can be easily sought, and quality of responses is better (Kassim \& Abdullah, 2010; Malhotra \& Dash, 2010). An disadvantage of direct administration of questionnaire is the bias of interviewer and the cost of administering (Malhotra \& Dash, 2010), but the possibility of quality responses led to the usage of same method. The responses were collected during August-November, 2019.

\section{RESULTS}

The sample under consideration comprised of 143 male respondents and 124 female respondents. The sample characteristics were analyzed using IBM SPSS Version 22, and SmartPLS 3.2. The respondents are representative of the demographic variables under consideration. Structural equation modeling (SEM) was used to assess the relationships in conceptual model. SmartPLS was selected for analyzing because it follows a variance-based approach for structural equation modeling. This approach is less sensitive to sample size than other applications like AMOS that are covariance-based (Bhattacherjee et al., 2008).

Before testing the hypothesized relationships, the reliability and validity of the scale was assessed. Table 1 shows the result for construct reliability through internal consistency (Cronbach's Alpha, $\alpha$ ) and Composite Reliability. The internal consistency was assessed through Cronbach's $\alpha$ for the factors compulsive buying behavior, information, materialism, and viewership were found to be $0.846,0.896,0.924$, and 0.768 respectively. The values are acceptable as they were found to be greater than the recommended value of 0.70 (Nunnally, 1978). After data screening, a total of 6 items (compulsive buying behavior $=2$, information $=1$, materialism $=2$, viewership $=1$ ) were removed due to low reliability and outliers. 
Table 1: Construct Reliability

\begin{tabular}{|l|c|c|c|c|}
\hline & $\begin{array}{c}\text { Cronbach's } \\
\text { Alpha }(\alpha)\end{array}$ & rho_A & $\begin{array}{c}\text { Composite } \\
\text { Reliability }\end{array}$ & $\begin{array}{c}\text { Average Variance } \\
\text { Extracted (AVE) }\end{array}$ \\
\hline Compulsive Buying Behavior & 0.846 & 0.901 & 0.899 & 0.695 \\
\hline Information & 0.896 & 0.899 & 0.928 & 0.762 \\
\hline Materialism & 0.924 & 0.931 & 0.946 & 0.814 \\
\hline Viewership & 0.768 & 0.81 & 0.845 & 0.577 \\
\hline
\end{tabular}

The validity of instrument was also assessed through convergent validity. The values of Average Variance Extracted (AVE) mentioned in table 1 are used to assess the convergent validity as suggested by Hair, Black, Babin, Anderson, and Tatham (2006). The AVE of all constructs as shown in the table was in the range 0.577-0.814, which exceed the recommended value of 0.5 (Hair et al., 2006). This establishes the measurement model and confirms both the construct validity and the convergent validity.

In addition to the construct reliability and the convergent validity, the scale must also achieve discriminant validity. To establish discriminant validity, the AVE for each construct must be greater than the shared variance among the constructs. The square root of each of the four constructs is greater than the correlation of other constructs. The values are provided in table 2. This establishes the discriminant validity.

Table 2: Discriminant Validity

\begin{tabular}{|c|c|c|c|c|}
\hline & $\begin{array}{c}\text { Compulsive } \\
\text { Buying Behavior }\end{array}$ & Information & Materialism & Viewership \\
\hline $\begin{array}{c}\text { Compulsive } \\
\text { Buying Behavior }\end{array}$ & 0.834 & & & \\
\hline Information & 0.493 & 0.873 & & \\
\hline Materialism & 0.421 & 0.393 & 0.902 & \\
\hline Viewership & 0.328 & 0.077 & 0.51 & 0.759 \\
\hline
\end{tabular}

\section{Direct Effects of Online Advertising:}

The path estimates and the corresponding t-values and p-values for online advertising were calculated through SmartPLS 3.2 with a bootstrapping technique. The results are presented in table 3. The relationships are significant $(p<0.05)$, which supports all hypotheses H1-H5. The standardized coefficients are in the hypothesized direction, and are used to assess the contribution of independent variables on compulsive buying behavior which supports H1-H5. The test also reveals a significant antecedent-consequence relationship of viewership, information with materialism and compulsive buying behavior; viewership, information, and materialism with compulsive buying behavior; and also materialism with compulsive buying behavior.

Table 3: Direct Effects of Online Advertising

\begin{tabular}{|l|c|c|c|c|}
\hline & & $\begin{array}{c}\text { Standard } \\
\text { Deviation } \\
\text { (STDEV) }\end{array}$ & $\begin{array}{c}\text { T Statistics } \\
\text { (|O/STDEV|) }\end{array}$ & $\begin{array}{c}\text { P } \\
\text { Values }\end{array}$ \\
\hline Information -> Compulsive Buying Behavior & 0.42 & 0.048 & 8.776 & 0 \\
\hline Information -> Materialism & 0.356 & 0.04 & 8.944 & 0 \\
\hline Materialism -> Compulsive Buying Behavior & 0.142 & 0.069 & 2.046 & 0.041 \\
\hline Viewership -> Compulsive Buying Behavior & 0.223 & 0.062 & 3.601 & 0 \\
\hline Viewership -> Materialism & 0.483 & 0.036 & 13.341 & 0 \\
\hline
\end{tabular}




\section{Indirect Effects of Online Advertising:}

The mediating effect of materialism was examined through the indirect effect of information and viewership on compulsive buying behavior. The results (Table 4) indicate that the indirect effect of materialism on compulsive buying behavior was significant. As both the direct and indirect effects of materialism on compulsive buying behavior were significant, thus materialism partially mediates the relationship of independent variable viewership and information. All hypotheses were accepted and the results of SmartPLS path model are shown in figure 2.

Table 4: Indirect Effects (Mediation) of Online Advertising

\begin{tabular}{|l|c|c|c|c|}
\hline & Estimate & $\begin{array}{c}\text { Standard } \\
\text { Deviation } \\
\text { (STDEV) }\end{array}$ & $\begin{array}{c}\text { T Statistics } \\
(\mid \text { O/STDEV|) }\end{array}$ & $\begin{array}{c}\text { P } \\
\text { Values }\end{array}$ \\
\hline Information -> Compulsive Buying Behavior & 0.051 & 0.025 & 2.022 & 0.044 \\
\hline Viewership -> Compulsive Buying Behavior & 0.069 & 0.035 & 1.985 & 0.048 \\
\hline
\end{tabular}

Figure 2: SmartPLS Path Model (Online Advertising)

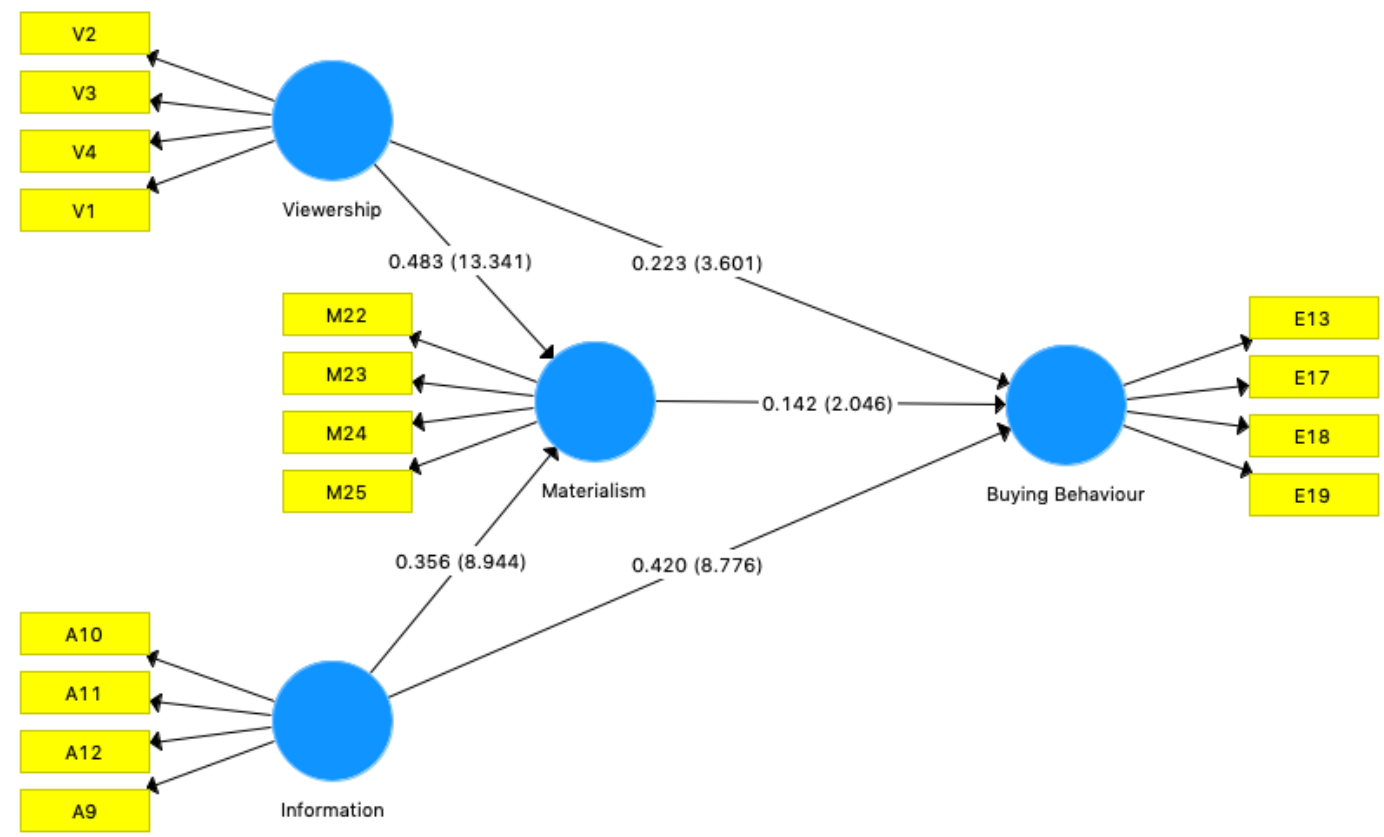

\section{Direct Effects of Television Advertising:}

The results for path estimates and corresponding t-values and p-values for television advertising are presented in table 5. The relationships are significant $(p<0.05)$, which supports all hypotheses H1-H5. The standardized coefficients are in the hypothesized direction, and are used to assess the contribution of independent variables on compulsive buying behavior which supports $\mathrm{H} 1-\mathrm{H} 5$. The test also reveals a significant antecedentconsequence relationship of viewership, information with materialism and compulsive buying behavior; viewership, information, and materialism with compulsive buying behavior; and also materialism with compulsive buying behavior. 
Table 5: Direct Effects of Television Advertising

\begin{tabular}{|l|c|c|c|c|}
\hline & Estimate & $\begin{array}{c}\text { Standard } \\
\text { Deviation } \\
\text { (STDEV) }\end{array}$ & $\begin{array}{c}\text { T Statistics } \\
(\mid \text { OSTDEV|) }\end{array}$ & $\begin{array}{c}\text { P } \\
\text { Values }\end{array}$ \\
\hline Information -> Compulsive Buying Behavior & 0.513 & 0.042 & 12.303 & 0 \\
\hline Information -> Materialism & 0.193 & 0.074 & 2.614 & 0.009 \\
\hline Materialism -> Compulsive Buying Behavior & -0.156 & 0.06 & 2.585 & 0.01 \\
\hline Viewership -> Compulsive Buying Behavior & 0.28 & 0.061 & 4.587 & 0 \\
\hline Viewership -> Materialism & 0.308 & 0.084 & 3.663 & 0 \\
\hline
\end{tabular}

\section{Indirect Effects of Television Advertising:}

The mediating effect of materialism was examined through the indirect effect of information and viewership on compulsive buying behavior. The results (Table 6) indicate that the indirect effect of materialism on compulsive buying behavior was significant for viewership but insignXificant for information. Thus materialism partially mediates the relationship of independent variable viewership and information. The results of SmartPLS path model are shown in figure 3.

Table 6: Indirect Effects (Mediation) of Television Advertising

\begin{tabular}{|l|c|c|c|c|}
\hline & Estimate & $\begin{array}{c}\text { Standard } \\
\text { Deviation } \\
\text { (STDEV) }\end{array}$ & $\begin{array}{c}\text { T Statistics } \\
(|\mathrm{O} / \mathrm{STDEV}|)\end{array}$ & $\begin{array}{c}\mathrm{P} \\
\text { Values }\end{array}$ \\
\hline Information -> Compulsive Buying Behavior & -0.03 & 0.016 & 1.856 & 0.064 \\
\hline Viewership -> Compulsive Buying Behavior & -0.048 & 0.022 & 2.147 & 0.032 \\
\hline
\end{tabular}

Figure 3: SmartPLS Path Model (Television Advertising)

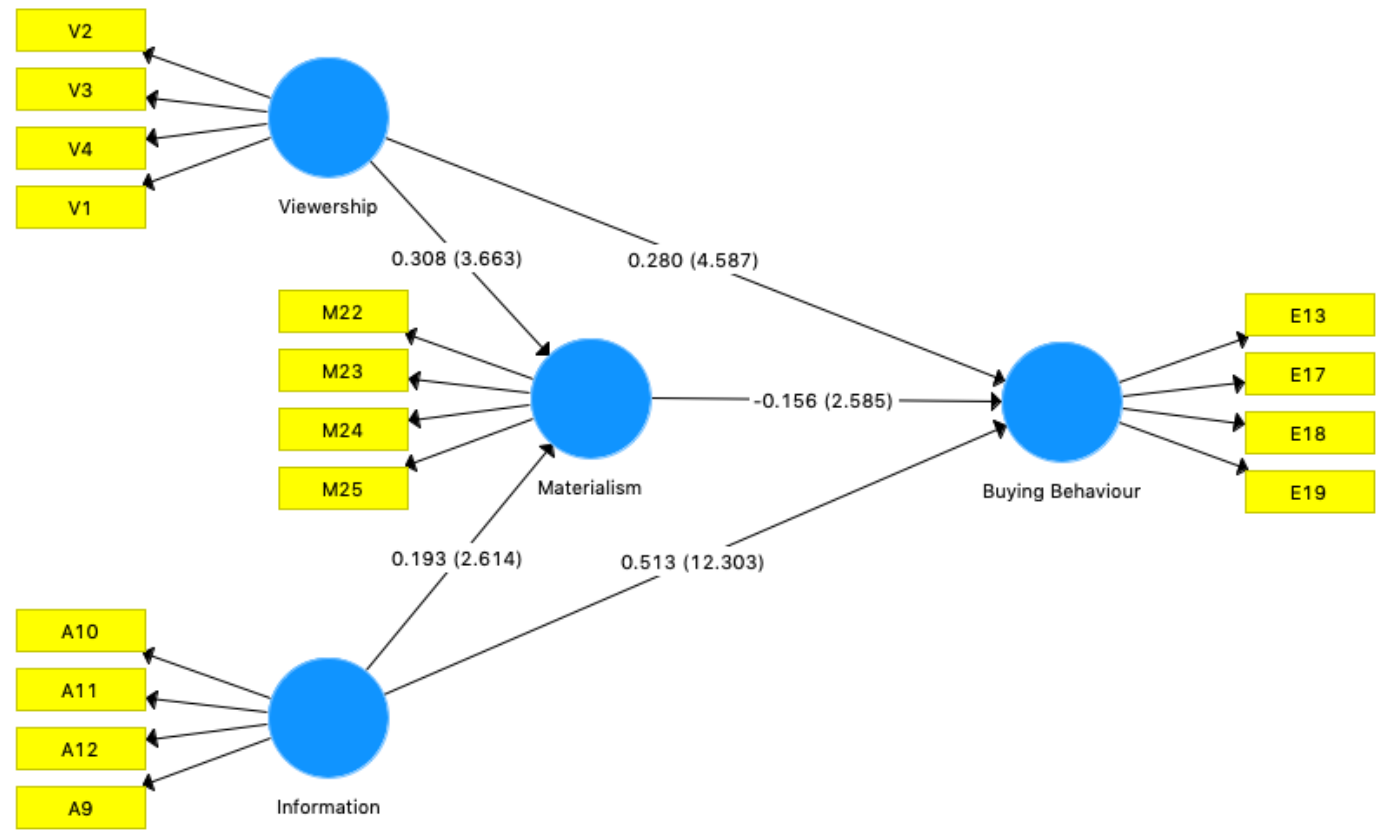

\section{DISCUSSION}

A company's goal can be achieved positively through sufficient advertising (Ahmad \& Mahfooz, 2018). The findings confirm that all proposed antecedents of compulsive buying behavior have 
a significant effect, which implies that any increase on them will have a significant effect. The proposed model also tested materialism as a mediator. In the conceptual framework, all individual hypotheses were supported and established a significant positive relationship for both online advertising and television advertising. The results confirm previous findings by authors focused on television advertising which found that information has a significant effect on materialism and buying behavior (Ahmad \& Mahfooz, 2018). This framework provides a better understanding of key influencers for materialism and compulsive buying behavior. This research can help marketing professionals to identify the factors responsible for the buying behavior of consumers, and can further help in developing strategies to sell more.

The research model was developed after a review of literature. Hypotheses were developed to test the model. After path analysis, significant positive relationship was found between viewership-compulsive buying behavior, viewership-materialism, information-compulsive buying behavior, information-materialism, and materialism-compulsive buying behavior. All the relationships in proposed model were found to be positive, and therefore all hypotheses H1-H5 were supported. All the relationships for online and television advertising were in the positive direction as conceptualized in the model.

For online advertising, viewership $(\beta=0.483)$ has a higher effect on materialism than information $(\beta=0.356)$ in the advertisements, and same is true for the effect on compulsive buying behavior as $\beta$ equals 0.42 for viewership as compared to 0.223 for information. For television advertising also, viewership has a higher effect than information because $\beta$ was found to be 0.308 as compared to 0.193 . But in television advertising, it was found that information $(\beta=0.513)$ has a higher effect on compulsive buying behavior than viewership $(\beta=0.28)$. for both online and television advertising, materialism has an effect on compulsive buying behavior, but it was found significant for online advertising. For television advertising, the effect was negligent.

Current research contributes to the existing literature as it extends the existing theoretical models by testing the predictors of compulsive buying behavior. This study also provides theoretical support for theories about antecedents of materialism and compulsive buying. Saudi Arabian consumers are very active on digital platforms and this study also provides evidence to strategy markers on which media to invest more for achievement of communication goals.

\section{ACKNOWLEDGEMENT}

The author extends her appreciation to the College of Business, Dar Al Uloom University for supporting the research.

\section{References}

Abe, M. (1997). A household-level television advertising exposure model. Journal of Marketing Research, 34(3), 394-405.

Ahmad, F. \& Mahfooz, Y. (2018). The effect of advertising information on materialism and buying behavior- An empirical study. Journal of Economics and Business, 1(4), 609-617.

Ashley, R., Granger, C. W., \& Schmalensee, R. (1980). Advertising and aggregate consumption: An analysis of causality. Econometrica: Journal of the Econometric Society, 48(5), 1149-1167.

Assad, S.W. (2008). The rise of consumerism in Saudi Arabian society. International Journal of Commerce and Management, 17(1/2). 73-104.

Belch, G. E., \& Belch, M. A. (2012). Advertising and Promotion: An Integrated Marketing Communications Perspective. London: McGraw-Hill Education. 
Buijzen, M., \& Valkenburg, P. M. (2003). The effects of television advertising on materialism, parent-child conflict, and unhappiness: A review of research. Journal of Applied Developmental Psychology, 24(4), 437-456.

Chan, K., \& Cai, X. (2009). Influence of television advertising on adolescents in China: An urban-rural comparison. Young Consumers, 10(2), 133-145.

Clow, K. E., \& Baack, D. E. (2014). Integrated Advertising, Promotion, and Marketing Communications. UK: Pearson Education.

Consumers International. (1999). Easy Targets: A Survey of Television Food and Toy Advertising to Children in Four Central European Countries, 1-55. London: Consumers International. Retrieved from

http://www.consumersinternational.org/news-and-media/resource-zone/easy-targets-survey-of-televisionfood-and-toy-advertising-to-children-in-four-central-european-countries/

Frideres, J. S. (1973). Advertising, buying patterns and children. Journal of Advertising Research, 13(1), 34-36.

Ghani, N. H. A. (2004). Television viewing and consumer behaviour. Young Consumers, 6(1), 66-74.

Ghani, N. H. A., \& Zain, O. M. (2004). Malaysian children's attitudes towards television advertising. Young Consumers. 5(3), 41-51.

Goldstein, J. (1999). Children and advertising- The research. International Journal of Advertising and Marketing to Children, 1(2), 113-118.

Greenberg, B. S., \& Brand, J. E. (1993). Television news and advertising in schools: The "Channel One" controversy. Journal of Communication, 43(1), 143-151.

Ha, H.-Y., John, J., Janda, S., \& Muthaly, S. (2011). The effects of advertising spending on brand loyalty in services. European Journal of Marketing, 45(4), 673-691.

Hair, J. F., Black, W. C., Babin, B. J., Anderson, R. E., \& Tatham, R. L. (2006). Multivariate Data Analysis. Upper Saddle River, NJ: Pearson Education.

Hair, J. F., Black, W. C., Babin, B. J., \& Anderson, R. E. (2010). Multivariate Data Analysis. Upper Saddle River, NJ: Pearson Education.

Harper, M. (1975). Advertising in a developing economy, opportunity and responsibility. European Journal of Marketing, 9(3), 215-223.

Hawkins, D. I., Mothersbaugh, D. L., \& Mookerjee, A. (2010). Consumer Behavior: Building Marketing Strategy. New Delhi: Tata McGraw-Hill.

Hoffman, E., Ho, M. Y., Chen, S. X., \& Ortiz, F. A. (2014). Retrospective Peak-Experiences among Chinese Young Adults in Hong Kong. The Journal of Humanistic Counseling, 53(1), 34-46.

Islam, T., Wei, J., Sheikh, Z., Hameed, Z., \& Azam, R. I. (2017). Determinants of compulsive buying behavior among young adults: The mediating role of materialism. Journal of Adolescence, 61, 117-130.

Jarlbro, G. (2001). Children and advertising on television: A survey of the research, 1994-2000. Nordicom Review, 22(2), 71-78.

Jayasinghe, L., \& Ritson, M. (2013). Everyday advertising context: An ethnography of advertising response in the family living room. Journal of Consumer Research, 40(1), 104-121.

Jin, H. S., \& Lutz, R. J. (2013). The typicality and accessibility of consumer attitudes toward television advertising: Implications for the measurement of attitudes toward advertising in general. Journal of Advertising, 42(4), 343357.

Karadeniz, M. (2013). The effects of advertisements on the consumers' brand preference of white goods, 34(1), 191-210. Retrieved from dosya.marmara.edu.tr/ikf/iib-dergi/2013-1/191.pdf

Kassim, N., \& Abdullah, N. A. (2010). The effect of perceived service quality dimensions on customer satisfaction, trust, and loyalty in e-commerce settings: A cross cultural analysis. Asia Pacific Journal of Marketing and Logistics, 22(3), 351-371.

Malhotra, N. K., \& Dash, S. (2010). Marketing Research: An Applied Orientation. New Delhi: Pearson Education.

Moore, R. L., \& Moschis, G. P. (1978). Teenagers' reactions to advertising. Journal of Advertising, 7(4), 24-30.

Moschis, G. P., \& Moore, R. L. (1982). A longitudinal study of television advertising effects. Journal of Consumer Research, 9(3), 279-286. 
Murry Jr., J. P., Lastovicka, J. L., \& Singh, S. N. (1992). Feeling and liking responses to television programs: An examination of two explanations for media-context effects. Journal of Consumer Research, 18(4), 441-451.

Murry Jr., J. P., \& Dacin, P. A. (1996). Cognitive moderators of negative-emotion effects: Implications for understanding media context. Journal of Consumer Research, 22(4), 439-447.

Neuman, W. L. (2007). Social Research Methods: Qualitative and Quantitative Approaches. New Delhi: Pearson Education.

North, E. J., \& Kotze, T. (2001). Parents and television Advertisements as consumer socialisation agents for adolescents: An exploratory study. Journal of Family Ecology and Consumer Sciences, 29(1), 91-99.

Nunnally, J. C. (1978). Psychometric Theory. Englewood-Cliffs, NJ: McGraw-Hill.

Pradhan, D., Israel, D., \& Jena, A. K. (2018). Materialism and compulsive buying behaviour: The role of consumer credit card use and impulse buying. Asia Pacific Journal of Marketing and Logistics. 30(5), 1239-1258.

Raghunathan, R., \& Corfman, K. (2006). Is happiness shared doubled and sadness shared halved? Social influence on enjoyment of hedonic experiences. Journal of Marketing Research, 43(3), 386-394.

Razzouk, N., \& Al-Khatib, J. (1993). The nature of television advertising in Saudi Arabia: Journal of International Consumer Marketing, 6(2), 65-90.

Richins, M. L., \& Dawson, S. (1992). A consumer values orientation for materialism and its measurement: Scale development and validation. Journal of Consumer Research, 19(3), 303-316.

Saraf, V. (2012). Efforts made by children to influence their parents' to accede purchase requests. Amity Management Review, 2(2), 26-33.

Schiffman, L. G., Kanuk, L. L., Kumar, S. R., \& Wisenblit, J. (2010). Consumer Behaviour. New Delhi: Pearson Education.

Segev, S., Shoham, A., \& Gavish, Y. (2015). A closer look into the materialism construct: the antecedents and consequences of materialism and its three facets. Journal of Consumer Marketing, 32(2), 85-98.

Shek, D.T.L., Ma, C., \& Lin, L. (2014). The Chinese adolescent materialism scale: Psychometric properties and normative profiles. International Journal on Disability and Human Development, 13(2), 285-295.

Shek, D.T.L., \& Pu, E. (2016). A review of research on materialism amongst children and adolescents in Hong Kong. International Journal of Child and Adolescent Health. 9(4), 455-467.

Shoham, A., Gavish, Y., \& Segev, S. (2015). A cross-cultural analysis of impulsive and compulsive buying behaviors among Israeli and US consumers: The influence of personal traits and cultural values. Journal of International Consumer Marketing, 27(3), 187-206.

Solomon, M. R. (2011). Consumer Behavior: Buying, Having, and Being. Upper Saddle River, NJ: Pearson Education. Sutherland, M. (1993). Advertising and the Mind of the Consumer. Crows Nest, NSW: Allen \& Unwin.

Tuu, H.H., Olsen, S.O., \& Cong, L.C. (2017). Patterns of Vietnamese buying behavior on luxury branded products. Asia Pacific Journal of Marketing and Logistics, 29(4), 778-795.

Valence, G., d'Astous, A., \& Fortier, L. (1988). Compulsive buying: Concept and measurement. Journal of Consumer Policy, 11(4), 419-433.

Valkenburg, P. M., \& Buijzen, M. (2005). Identifying determinants of young children's brand awareness: Television, parents, and peers. Journal of Applied Developmental Psychology, 26(4), 456-468.

Ward, S., \& Wackman, D. (1971). Family and media Influences on adolescent consumer learning. The American Behavioral Scientist, 14(3), 415-427.

Woo, J., Ahn, J., Lee, J., \& Koo, Y. (2015). Media channels and consumer purchasing decisions. Industrial Management \& Data Systems, 115(8), 1510-1528.

Wulfemeyer, K. T., \& Mueller, B. (1992). Channel One and commercials in classrooms: Advertising content aimed at students. Journalism \& Mass Communication Quarterly, 69(3), 724-742.

Yavas, U., \& Abdul-Gader, A. (1993). Impact of TV commercials on Saudi children's purchase behaviour. Marketing Intelligence and Planning, 11(2), 37-43. 